A-rkivoc

Free to Authors and Readers
A Platinum Open Access Journal

for Organic Chemistry
Paper

Arkivoc 2021, part viii, 130-144

\title{
Addition of Heteroatom Nucleophiles to Ketene Dimers
}

\author{
Ahmad A. Ibrahima, Gero D. Harzmann ${ }^{a}$, Divya Nalla ${ }^{a}$, Beth Elledge ${ }^{a}$, Max Van Raaphorsta , \\ Nessan J. Kerrigan ${ }^{b}$ \\ ${ }^{a}$ Department of Chemistry, Oakland University, 2200 N. Squirrel Road, Rochester, MI 48309-4477, USA \\ ${ }^{b}$ School of Chemical Sciences, Dublin City University, Glasnevin, Dublin 9, Ireland \\ Email: nessan.kerrigan@dcu.ie
}

Received 12-05-2020

Accepted 03-29-2021

Published on line $04-20-2021$

\section{Abstract}

An investigation of the reaction of heteroatom nucleophiles with ketene dimers, with an emphasis on a discussion of diastereoselectivity where applicable, is described. During this study we focused on the reaction of nitrogen-centred nucleophiles (Weinreb amine, lithiated Weinreb amide, and an amino acid derivative), and oxygen-centred nucleophiles (alkoxides). Simple Weinreb amide derivatives of ketene heterodimers were formed in moderate to excellent yield (up to 89\%) and excellent retention of chirality (ee up to 91\%), albeit with poor diastereoselectivity. The 2-pyridone-catalysed amine ring-opening was also applied to the asymmetric synthesis of a cinnabaramide A intermediate. Finally, the use of amide and alkoxide ring-opening nucleophiles enabled the development of a sequential one-pot reaction with benzaldehyde to afford $\delta$-lactones in moderate yields (up to $47 \%$ ) but with good diastereoselectivity (dr up to $24: 1$ ).

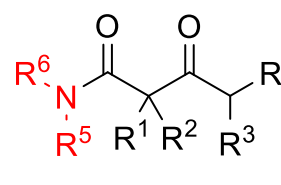

yield up to $89 \%$ dr up to $1.9: 1$

For cinnabaramide A intermediate: dr 49:1
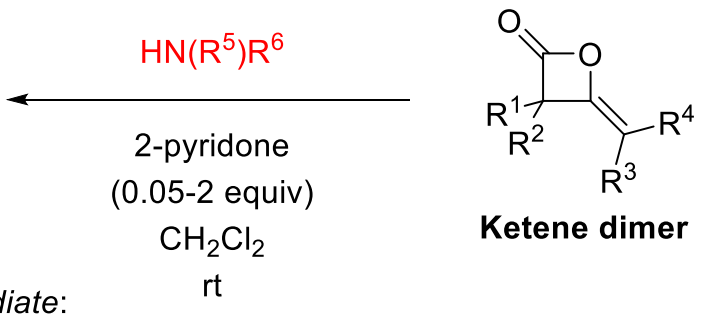

Ketene dimer
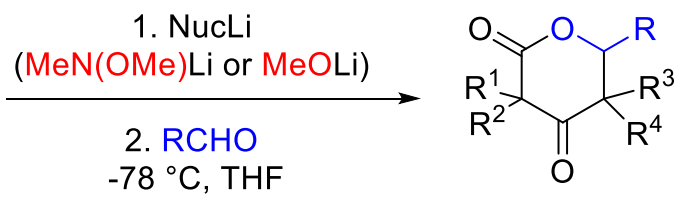

yield $40-47 \%$ dr up to $24: 1$

Keywords: Diastereoselective, enantioselective, asymmetric synthesis, ketene dimer, Weinreb amide, $\delta$ lactone. 


\section{Introduction}

Ketene dimer $\beta$-lactones have a long and distinguished history of utility in organic synthesis. ${ }^{1-8}$ Ketene dimers are among the most interesting $\beta$-lactones from a synthetic use standpoint due to the presence of an exocyclic double bond with potential for use as a nucleophile following ring-opening reactions. ${ }^{9-13}$ Calter and co-workers, and Romo's group have demonstrated that aldoketene homodimer $\beta$-lactones can be used as building blocks for polypropionate synthesis. ${ }^{9-14}$ Racemic ketene heterodimers have also been shown to function effectively as intermediates in the synthesis of complex molecules, such as salinosporamide $A$ and cinnabarmide $A .{ }^{15,16} \mathrm{~A}$ few years ago, we reported methods for the asymmetric synthesis of ketene homodimers and ketene heterodimers from disubstituted ketenes (Scheme 1). ${ }^{17-20}$ We had also investigated addition of $\mathrm{H}$ - and C-centered nucleophiles to ketene dimers, as well as more recently hydrogenation/hydrogenolysis of ketene heterodimers. ${ }^{21-26}$ Herein, we describe our studies investigating the reaction of heteroatom nucleophiles with ketene dimers, with an emphasis on a discussion of scope and diastereoselectivity wherever applicable. During this study we focused on the reaction of nitrogen-centered nucleophiles (Weinreb amine, lithiated Weinreb amide, and an amino acid derivative), and oxygen-centered nucleophiles (metal alkoxides).

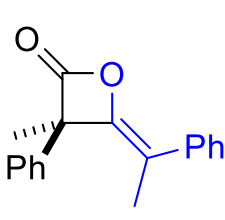

$2 e$

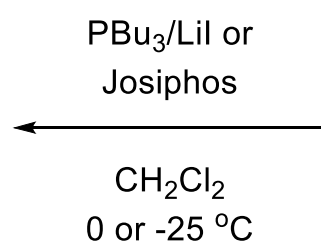

Homodimerization

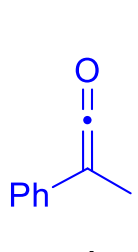

1

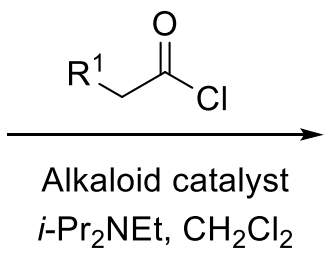

$-25^{\circ} \mathrm{C}$

Heterodimerization

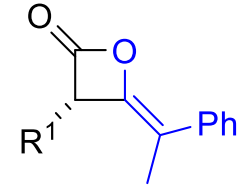

2a-2d

Z-isomer

Scheme 1. Our previous work.

\section{Results and Discussion}

During our initial studies we investigated the reaction of Weinreb amine with a variety of ketene heterodimers to access synthetically useful enantioenriched Weinreb amides. ${ }^{19,20,27}$ The reaction conditions chosen, 1-2 equiv Weinreb amine and ca. 5-10 mol\% 2-pyridone, were originally introduced by Calter's group for the synthesis of dipropionate synthons. ${ }^{9}$ The ketene heterodimer test substrates (2a-2d and $\mathbf{2 f}$ ) were prepared through the alkaloid-catalyzed ketene heterodimerization reaction, as previously described by our group. ${ }^{19,20}$ Reaction with methylphenylketene homodimer $( \pm)$-2e was also examined and this was produced through the phosphinecatalyzed homodimerization reaction. ${ }^{17,18}$

In most cases, Weinreb amide formation proceeded in good to excellent yields (Table 1, entries 1,2, 57). Moderate yields were only observed in those cases (entries 3 and 4) where ketene dimerization did not proceed in very good yield (yield is for two steps from ketene in most cases). Enantiomeric excess for each Weinreb amide was good to excellent (76-95\% ee) owing to the highly enantioselective nature of the alkaloidcatalyzed ketene heterodimerization process. ${ }^{19,20}$ However diastereoselectivity for the formation of 3c-3e was poor due to the lack of selectivity in the protonation/proton transfer step of the 2-pyridone-catalyzed reaction. ${ }^{9}$ 
Table 1. Synthesis of Weinreb amides from ketene/ketene dimers

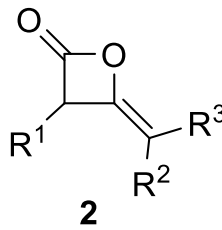

$(R)$ or $(S)$

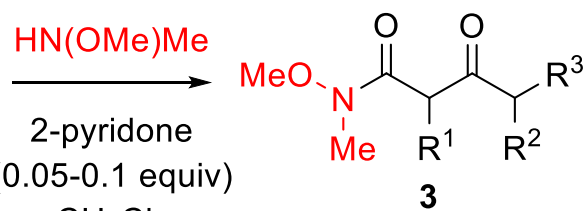

$\mathrm{CH}_{2} \mathrm{Cl}_{2}$

rt

\begin{tabular}{cccccccccc}
\hline Entry & $\mathrm{SM}^{\mathrm{a}}$ & $\begin{array}{c}\text { \% ee } \\
\text { of } \mathbf{2}^{\mathrm{b}}\end{array}$ & $\mathrm{R}^{1}$ & $\mathrm{R}^{2}$ & $\mathrm{R}^{3}$ & Product 3 $^{\text {\% yield of 3c }}$ & $\begin{array}{c}\mathrm{dr} \text { of } \\
\mathbf{3}^{\mathrm{d}}\end{array}$ & $\begin{array}{c}\text { \% ee } \\
\text { of } \mathbf{3}^{\mathrm{e}}\end{array}$ \\
\hline 1 & $(R)-\mathbf{2 a}$ & $\mathrm{nd}$ & $\mathrm{Me}$ & $\mathrm{Me}$ & $\mathrm{Me}$ & $(R)-\mathbf{3 a}$ & 79 & $\mathrm{na}$ & 91 \\
2 & $(S)-\mathbf{2 a}$ & $\mathrm{nd}$ & $\mathrm{Me}$ & $\mathrm{Me}$ & $\mathrm{Me}$ & $(S)-\mathbf{3 a}$ & 89 & $\mathrm{na}$ & 95 \\
3 & $(R)-\mathbf{2 b}$ & $\mathrm{nd}$ & $\mathrm{OAc}$ & $\mathrm{Me}$ & $\mathrm{Me}$ & $(R)-\mathbf{3 b}$ & 52 & $\mathrm{na}$ & 76 \\
4 & $(S)-\mathbf{2 b}$ & $\mathrm{nd}$ & $\mathrm{OAc}$ & $\mathrm{Me}$ & $\mathrm{Me}$ & $(S)-\mathbf{3 b}$ & 57 & $\mathrm{na}$ & 91 \\
5 & $(S)-\mathbf{2 c}$ & 98 & $\mathrm{Me}$ & $\mathrm{Me}$ & $\mathrm{Ph}$ & $\mathbf{3 c}$ & 84 & $1.3: 1$ & $\mathrm{nd}$ \\
6 & $(S)-\mathbf{2 d}$ & 99 & $\mathrm{Me}$ & $\mathrm{Et}$ & $\mathrm{Ph}$ & $\mathbf{3 d}$ & 67 & $1.9: 1$ & $\mathrm{nd}$ \\
7 & $( \pm)-\mathbf{2 e}$ & $\mathrm{na}$ & $\mathrm{Me}, \mathrm{Ph}$ & $\mathrm{Me}$ & $\mathrm{Ph}$ & $( \pm)-\mathbf{3 e}$ & 72 & $1.4: 1$ & $\mathrm{na}$ \\
\hline
\end{tabular}

${ }^{\text {a }} \mathrm{SM}=$ starting material (ketene heterodimer or ketoketene homodimer). ${ }^{\mathrm{b}}$ ee for $\mathbf{2}$ not determined in most cases as $\mathbf{2}$ was not isolated but instead was directly converted to 3. ${ }^{c} \%$ yield $=$ isolated yield for both diastereomers of 3. Excepting entries 5-7, yield for two steps from acyl chloride. ${ }^{d}$ dr determined by GC-MS or ${ }^{1} \mathrm{H}$ NMR analysis of crude 3 . ${ }^{\text {e } \%}$ ee determined by chiral HPLC analysis.

The ring-opening conditions utilized in Table 1 were then applied to the synthesis of a cinnabaramide $A$ precursor from a silyl-substituted ketene heterodimer. We determined that heterodimer (-)-2f, derived from TMS-ketene and $n$-hexylketene, can be used to access a precursor to cinnabaramide A (Table 2). ${ }^{15,16}(-)$-2f was subjected to reaction with protected serine derivative 4 under 2-pyridone catalysis conditions. A number of variations on the standard reaction conditions of Table 1 were then explored. Ultimately, the reaction proceeded in good yield (82\%) and with moderate diastereoselectivity ( $\mathrm{dr} 3: 1)$, after heating $\left(50^{\circ} \mathrm{C}\right)$ with serine derivative 4 ( 2 equiv) and excess 2-pyridone ( 2 equiv), and following desilylation with TBAF (Table 2, entry 1). Since enantioenriched reactants were used it was necessary to determine whether erosion of enantiomeric integrity of (-)-2f under the reaction conditions was leading to moderate diastereoselectivity. After running the reaction for $55 \mathrm{~h}$, some $\mathbf{2 f}$ was isolated and HPLC analysis was performed on a prepared Weinreb amide derivative 3f. It was determined that the ee of heterodimer $\mathbf{2} \mathbf{f}$ did not undergo erosion under the reaction conditions. A series of control experiments were then performed to investigate whether any of the reactants were acting as a base and causing epimerization of 5 under the reaction conditions. $5(\mathrm{dr}=24: 1)$ in THF was heated at $50{ }^{\circ} \mathrm{C}$ for $24 \mathrm{~h}$, but after this time there was no change in dr observed. Next a mixture of 5 and 4 in THF was heated at $50{ }^{\circ} \mathrm{C}$ for $20.5 \mathrm{~h}$. But again, there was no change in dr observed. Then 2-pyridone ( 2 equiv) was added to a solution of 4 and $5 \mathrm{in} \mathrm{THF}$, and the reaction mixture was heated at $50{ }^{\circ} \mathrm{C}$ for $22 \mathrm{~h}$. However, there still was no observable change in $\mathbf{d r}$. This left the possibility that carbanion generated through desilylation of $\mathbf{2 f}$ was causing epimerization of $\mathbf{5}$. To eliminate epimerization, we introduced KF, to aid desilylation of $\mathbf{2 f}$, along with acetic acid to act as a mild proton source which would help quench the resulting carbanion (Table 2 entries 2-4). In experiments conducted in the presence of acetic acid, diastereoselectivity improved dramatically (Table 
2, entries 3 and 4), albeit at the cost of lower conversion to $\mathbf{5}$ and increased decomposition of $\mathbf{2 f}$. We surmise that the mild proton source protonates desilylated $\mathbf{2 f}$, effectively inhibiting it from acting as a base.

Table 2. Synthesis of cinnabaramide A precursor from ketene heterodimer $\mathbf{2 f}$

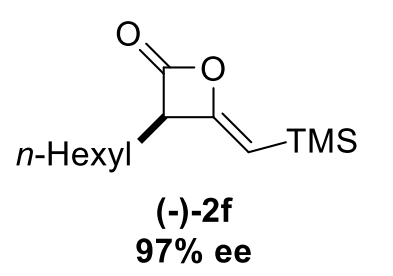

$97 \%$ ee<smiles>CNC(COCc1ccccc1)C(=O)O[AlH2]</smiles>

4

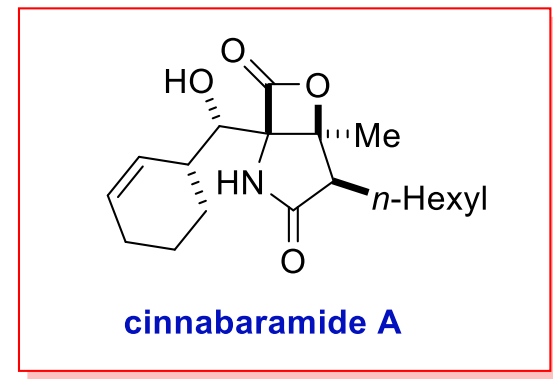

1. 2-Pyridone (2 equiv) THF, $50^{\circ} \mathrm{C}, 55 \mathrm{~h}$

2. TBAF, rt

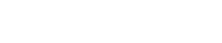

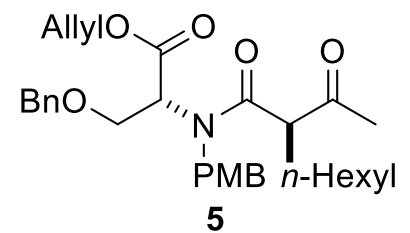

cinnabaramide A precursor

\begin{tabular}{ccclll}
\hline Entry & $\begin{array}{c}\mathbf{2 f} \\
\text { (Equiv) }\end{array}$ & $\begin{array}{c}\mathbf{4} \\
\text { (Equiv) }\end{array}$ & Additive & $\begin{array}{l}\text { \% Conv }(\% \\
\text { yield) of } \mathbf{5}^{\mathrm{a}}\end{array}$ & dr of $\mathbf{5}^{\mathbf{b}}$ \\
\hline 1 & 1 & 2 & None & $(82)$ & $3: 1$ \\
2 & 1 & 2 & $\mathrm{KF}$ & 48 & $4.6: 1$ \\
3 & 1 & 2 & $\mathrm{KF}+\mathrm{AcOH}$ & $40(16)$ & $49: 1$ \\
4 & 1 & 1 & $\mathrm{KF}+\mathrm{AcOH}$ & 25 & $99: 1$ \\
\hline
\end{tabular}

a \% yield = isolated yield for both diastereomers of $5 .{ }^{b} \mathrm{dr}$ determined by ${ }^{1} \mathrm{H}$ NMR analysis of crude 5 .

Having observed that the 2-pyridone-catalyzed amine ring-opening proceeded effectively, from conversion standpoint, for a number of diversely substituted ketene dimers, we then proceeded to investigate the possibility of sequential reactions of ketene heterodimer-derived lithium enolates with an aldehyde (Table 3). ${ }^{28,29}$ Such a reaction would allow for assembly of complex polyketide derivatives with potentially up to three stereogenic centers, with two being set in the aldol reaction. Lithiated Weinreb amine was utilized as the preferred nucleophile, as Calter's group had success with it in the ring-opening of methylketene homodimer. ${ }^{10}$ 
Table 3. Synthesis of $\delta$-lactone from ketene heterodimers

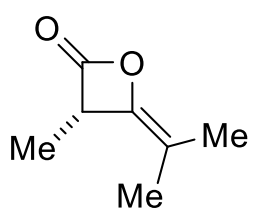

2a

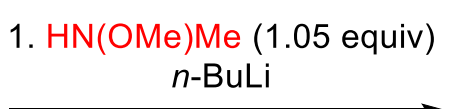

2. $\mathrm{PhCHO}$ $-78^{\circ} \mathrm{C}, \mathrm{THF}$

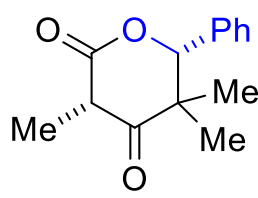

$6 a$

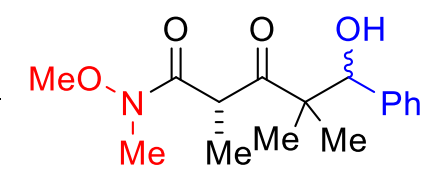

$7 \mathbf{a}$

\begin{tabular}{cccccc}
\hline Entry & [2a] & \% Yield ${ }^{\mathrm{a}}$ 6a & \% Yield 7a & dr 6a & dr 7a \\
\hline 1 & $0.1 \mathrm{M}$ & 29 & 20 & $24: 1$ & $1: 1$ \\
2 & $0.2 \mathrm{M}$ & 40 & - & $24: 1$ & - \\
\hline
\end{tabular}

a \% Yield $=$ isolated yield for both diastereomers of $6 \mathrm{a} .{ }^{\mathrm{b}} \mathrm{dr}$ determined by GC-MS and ${ }^{1} \mathrm{H}$ NMR analysis of crude $\mathbf{6 a}$.

The ketene heterodimer 8 -lactone $\mathbf{2 a}$ was converted to a lithium enolate using LiN(OMe)Me (prepared by the reaction of $\mathrm{N}, \mathrm{O}$-dimethylhydroxylamine with $n$-butyllithium in $2.5 \mathrm{M}$ hexane) as ring-opening agent. The lithium enolate derived from $\mathbf{2 a}$ was subjected to reaction with benzaldehyde, and surprisingly led to the formation of $\delta$-lactone $6 a(29 \%, d r=24: 1)$ along with the acyclic aldol product $7 a(20 \%, d r=1: 1)$. When the concentration of the heterodimer in THF was increased to $0.2 \mathrm{M}$ only the $\delta$-lactone was formed in $40 \%$ yield and with high diastereoselectivity $(d r=24: 1)$. However, the ee of $6 a$ was determined to be only $40 \%$ (compared to starting ee of $\mathbf{9 5 \%}$ for $\mathbf{2 a}$ ), which suggested that significant racemization of $\mathbf{2} \mathbf{a}$, or an enolate intermediate, occurred under the reaction conditions. The reaction of silyl-substituted ketene heterodimers (e.g. 2f) were also examined under these reaction conditions but led to the formation of a complex mixture rather than the desired acyclic aldol or $\delta$-lactone product.

We then investigated the reaction of methylphenylketene homodimer $( \pm)-\mathbf{2 e}$ with lithiated Weinreb amine and a number of lithiated alkoxides, and a sequential one-pot reaction of the enolate intermediate with various aldehydes (Table 4). Methylphenylketene homodimer $( \pm)$-2e was prepared through the $\mathrm{PBu}_{3}$-Lilcatalyzed homodimerization of pre-prepared methylphenylketene. ${ }^{17,18}$ Disappointingly, ring-opening with lithiated Weinreb amine, and sequential reaction with benzaldehyde was unsuccessful leading to a complex product mixture. Subsequently, optimization studies involving ring-opening with MeOLi were more successful and revealed that the optimal temperature for enolate intermediate formation was $c a .0^{\circ} \mathrm{C}$. Quenching of the enolate at room temperature led to the ketoester $( \pm)$-8e being obtained in quantitative yield and with moderate diastereoselectivity ( $\mathrm{dr}$ 1.6:1). The low diastereoselectivity in the latter transformation was understandable given the lack of diastereofacial bias possible in protonation of the acyclic enolate intermediate. This contrasted with the results of our study involving ring-opening of ketoketene homodimers with alkyllithiums where good levels of diastereoselectivity were observed (dr up to 9:1) due to quenching of a putative cyclic intermediate. ${ }^{21,23}$ Attempts to carry out a sequential aldol reaction by addition of an aldehyde to the enolate intermediate solution required a considerable amount of optimization. For the sequential one-pot enolate formation-aldol reaction, benzaldehyde was chosen as the test substrate (Table 4). Interestingly, ring-opening with MeOLi, followed by enolate trapping with benzaldehyde led to the formation of product as the $\delta$-lactone $( \pm)$ - 6 e rather than the acyclic ester product derived from straightforward aldol reaction. ${ }^{10,13}$ We surmised that cyclization, with loss of $\mathrm{MeO}^{-}$, occurred following aldol reaction (Scheme 2). From Table 4, it is clear that MeOLi was the most effective ring-opening nucleophile, with sterically bulky alkoxides ( $i$-PrOLi and $t$-BuOLi) failing to provide reasonable levels 
of conversion. Increasing the number of equivalents of benzaldehyde beyond $c a .1 .5$ equiv led to less clean reactions and slightly lower yield of the desired $\delta$-lactone (Table 4 entry 5 ).

Table 4. Optimization of $\delta$-lactone formation from ketene homodimer

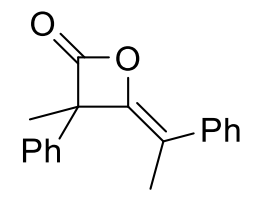

$( \pm)-2 e$

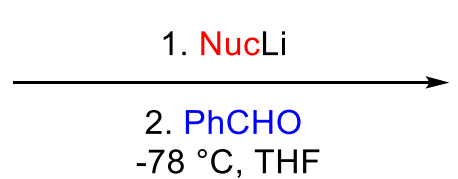

$-78{ }^{\circ} \mathrm{C}, \mathrm{THF}$<smiles>CC(=O)C(C)(C(=O)C(C)c1ccccc1)c1ccccc1</smiles>

$( \pm)-8 e$

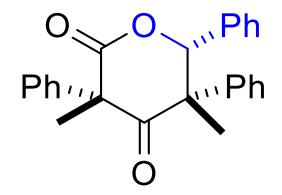

$( \pm)-6 e$

\begin{tabular}{|c|c|c|c|c|c|c|}
\hline Entry & $\mathrm{NucLi}^{\mathrm{a}}$ & $\begin{array}{l}\mathrm{PhCHO} \\
\text { (Equiv) }\end{array}$ & Additive & $\begin{array}{l}\text { \% Conv } \text { Ce }^{\mathrm{8e}} \\
\text { (\% Yield 8e) }\end{array}$ & $\begin{array}{c}\% \text { Conv 6e } \\
(\% \text { Yield } 6 e)^{c}\end{array}$ & $d r$ of $6 e^{d}$ \\
\hline 1 & MeOLi & 0 & - & >99 (>99) & - & $1.6: 1(8 e)$ \\
\hline 2 & MeOLi & 1.0 & - & nd & $71(26)$ & 9:1 \\
\hline 3 & MeOLi & 1.1 & - & nd & $63(43)$ & $9: 1$ \\
\hline 4 & MeOLi & 1.5 & - & nd & $68(47)$ & $9: 1$ \\
\hline 5 & MeOLi & 2.0 & - & 29 & $45(-)$ & $9: 1$ \\
\hline 6 & MeOLi & 1.1 & $(c-\mathrm{Hex})_{2} \mathrm{BCl}$ & 6 & $13(-)$ & nd \\
\hline 7 & MeOLi & 1.0 & $\mathrm{ZnCl}_{2}$ & 80 & $1(-)$ & nd \\
\hline 8 & i-PrOLi & 1.1 & - & nd & $8(-)$ & nd \\
\hline 9 & $t$-BuOLi & 1.1 & - & nd & $1(-)$ & nd \\
\hline
\end{tabular}

${ }^{\mathrm{a}} \mathrm{NuCLi}=$ nucleophile. ${ }^{\mathrm{b}}$ Conv $=$ conversion as determined by GC-MS analysis of crude product.

${ }^{c} \%$ Yield $=$ isolated yield for both diastereomers of 6 e. ${ }^{d}$ dr determined by GC-MS analysis of crude product.

Other aldehydes (valeraldehyde and cyclohexanecarboxaldehyde) were also examined under the reaction conditions but provided less impressive results (42\% for valeraldehyde-derived $\delta$-lactone $6 \mathrm{f}$, but with poor dr 4:2:1). Ethylphenylketene homodimer was also exposed to the optimized reaction conditions (with $\mathrm{ZnCl}_{2}$ as additive) but underwent incomplete conversion to $\delta$-lactone (up to $32 \%$ conv) and with poor diastereoselectivity (dr 2:2:2:1).

The proposed mechanism for the $\delta$-lactone forming reaction is shown in Scheme 2 . The lithiated nucleophile (Weinreb amide or alkoxide) would add to the carbonyl of ketene dimer 2. Ring-opening would provide lithium enolate $\mathbf{9}$ as an intermediate. Enolate $\mathbf{9}$ would then engage in a diastereoselective aldol reaction with added aldehyde to access aldolate 10. Diastereoselectivity would be achieved through a closed Zimmerman-Traxler transition state, in which the phenyl substituent at the chiral center of enolate $9 e\left(R^{1}=P h\right.$, from methylphenylketene dimer $\mathbf{2 e}$ ) is the large substituent, forcing the aldehyde to react with the $\pi$-face of the enolate anti to the phenyl substituent. We propose that this transition state assembly would favor formation of the syn,syn-diastereomer (Scheme 2), in agreement with the outcome of Calter's results on the aldol reaction of methylketene dimer-derived enolates. ${ }^{10,13,28,29} 6$-Exo-trig cyclisation of aldolate alkoxide 10 onto pendant amide or ester carbonyl would then furnish $\delta$-lactone 6 . 
<smiles>[R]C([R])=C1OC(=O)C1[R2]</smiles>

2<smiles>[R]C([R])=C1O[AlH]OC(C#N)C1([R])[R]</smiles>

9<smiles>[Y][PH2+]</smiles><smiles>[R]C(=O)C([R])([R])C(=O)C([R])[R]</smiles>

1. NucLi (MeN(OMe)Li or MeOLi)

2. $\mathrm{PhCHO}$ $-78^{\circ} \mathrm{C}, \mathrm{THF}$<smiles>[R]C1C(=O)OC([R])C([R])([R])C1=O</smiles>

6

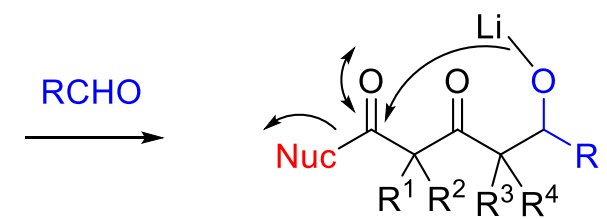

10 $\mathrm{H}^{+}$<smiles>[R]C(O)C([R])([R])C(=O)C([R])([R])C(N)=O</smiles>

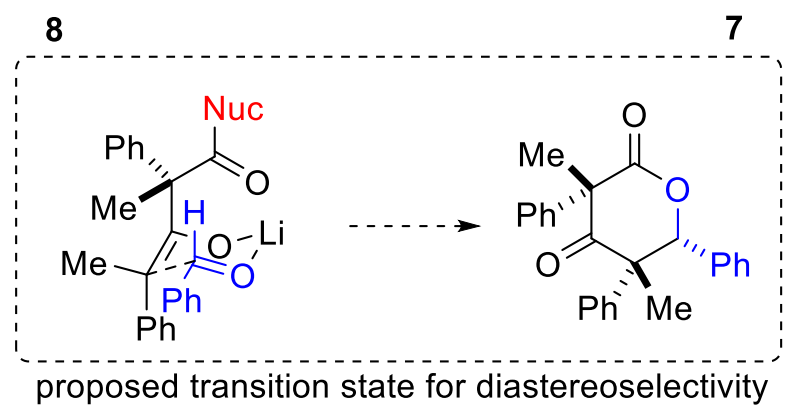

Scheme 2. Proposed mechanism for the formation of $\delta$-lactone 6.

\section{Conclusions}

In conclusion, we report that a range of ketene dimers (heterodimers and ketoketene homodimer) undergo 2pyridone-catalyzed ring-opening reaction with Weinreb amine to access simple Weinreb amides in moderate to excellent yields and with good enantiomeric excesses. Optimization of the 2-pyridone-catalyzed asymmetric synthesis of a cinnabaramide A intermediate was reported. A one-pot transformation of ketene dimers into $\delta$ lactones through a sequential Weinreb amide or alkoxide-mediated ring-opening/aldol reaction/cyclization was also accomplished in moderate yields (40-47\%) but with very good diastereoselectivity for select examples. 


\section{Experimental Section}

General. THF was freshly distilled from benzophenone ketyl radical under nitrogen prior to use, while Hünig's base (diisopropylethylamine) was distilled from calcium hydride and $\mathrm{N}, \mathrm{N}$-dimethylethylamine was distilled from potassium hydroxide under nitrogen. ${ }^{30}$ Most anhydrous solvents $\left(\mathrm{CH}_{2} \mathrm{Cl}_{2}\right.$ and $\left.\mathrm{Et}_{2} \mathrm{O}\right)$ were obtained by passing through activated alumina columns on a solvent purification system. 2-Pyridone and $O$-benzyl- $D$-serine was purchased from Aldrich Chemical Co. Octanoyl chloride and trimethylsilyl chloride were purchased from Aldrich Chemical Co. and distilled prior to use. ${ }^{30}$ latrobeads (Bioscan, 6RS-8060, 60 $\mu \mathrm{M}$ particle size), and TLC plates (Sorbent Technologies, UV254, $250 \mu \mathrm{M}$ ) were used as received. Methylphenylketene, ethylphenylketene, dimethylketene and TMS-ketene were prepared according to literature procedures. ${ }^{31-35}$ TMS-quinine, Mequinidine and Me-quinine were synthesized according to literature procedure. ${ }^{7,36}$

NMR spectra were recorded on a Bruker DPX Avance 200 spectrometer ( $200 \mathrm{MHz}$ for ${ }^{1} \mathrm{H}$ and $50 \mathrm{MHz}$ for ${ }^{13} \mathrm{C}$ ) and on a Bruker Biospin AG 400 spectrometer (400 MHz for ${ }^{1} \mathrm{H}$ and $100 \mathrm{MHz}$ for ${ }^{13} \mathrm{C}$ ). NMR chemical shifts were reported relative to TMS $(0 \mathrm{ppm})$ for ${ }^{1} \mathrm{H}$ and to $\mathrm{CDCl}_{3}(77.23 \mathrm{ppm})$ for ${ }^{13} \mathrm{C}$ spectra. High resolution mass spectra were obtained on an Agilent Technologies 6520 Accurate Mass Q-TOF LC-MS instrument at Oakland University (with ESI as the ionization method). Low resolution mass spectra were recorded on a GC/MS Hewlett Packard HP 6890 GC instrument with a 5973 mass selective detector, and using a Restek Rtx-CL Pesticides2 GC column (30 m, 0.25 mm ID). IR spectra were recorded on a Bio Rad FTS-175C spectrometer. Optical rotations were measured on a Rudolph DigiPol 781 TDV automatic polarimeter.

Analytical high performance liquid chromatography (HPLC) was performed using a Daicel Chiralpak AD column $(0.46 \mathrm{~cm} \times 25 \mathrm{~cm})$, OD-H column $(0.46 \mathrm{~cm} \times 25 \mathrm{~cm})$, or an AS-H column $(0.46 \mathrm{~cm} \times 25 \mathrm{~cm})$ (Daicel Chemical Ind., Ltd.) on a Perkin Elmer Flexar instrument attached with diode array detector (deuterium lamp, 190-600 nm) with HPLC-grade isopropanol and hexanes as the eluting solvents. Analytical gas chromatography (GC) was performed using an Astec CHIRALDEX ${ }^{\mathrm{TM}}$ B-DM column (30 $\mathrm{m} \times 0.25 \mathrm{~mm} \times 0.12 \mathrm{um}$ ) on a Perkin Elmer Clarus 500 instrument.

Procedure for preparation of $(\boldsymbol{R})-\mathbf{N}$-methoxy-N,2,4-trimethyl-3-oxopentanamide $((\boldsymbol{R})$-3a). Dimethylketene $(102 \mathrm{mg}, 1.46 \mathrm{mmol})$ in $\mathrm{Et}_{2} \mathrm{O}(2.4 \mathrm{~mL})$ was added to a solution of Me-quinine $(50 \mathrm{mg}, 0.15 \mathrm{mmol})$, and $\mathrm{LiClO}_{4}$ (155 mg, $1.46 \mathrm{mmol}$ ) in $\mathrm{CH}_{2} \mathrm{Cl}_{2}$ dichloromethane $(4.4 \mathrm{~mL})$ and $\mathrm{Et}_{2} \mathrm{O}(1 \mathrm{~mL})$ at $-25^{\circ} \mathrm{C}$. Hünig's base $(94 \mathrm{mg}, 0.73$ $\mathrm{mmol}$ ) was then added. Propionyl chloride $\left(67 \mathrm{mg}, 0.73 \mathrm{mmol}\right.$ ) in $\mathrm{CH}_{2} \mathrm{Cl}_{2}$ dichloromethane $(0.5 \mathrm{~mL})$ was added over $1 \mathrm{~h}$ to the above solution, the mixture was stirred for $3 \mathrm{~h}$ at $-25^{\circ} \mathrm{C}$ and then the reaction was quenched by the addition of water $(5 \mathrm{~mL})$. The layers were separated and the aqueous layer was washed with $\mathrm{CH}_{2} \mathrm{Cl}_{2}$ dichloromethane $(2 \times 5 \mathrm{~mL})$. The combined organics were dried over anhydrous $\mathrm{Na}_{2} \mathrm{SO}_{4}$ and then concentrated to about $10 \mathrm{~mL}$. The solution was diluted with pentane $(10 \mathrm{~mL})$ and passed through a plug of neutral silica ( $10 \mathrm{~g}$ ), eluting with $50 \% \mathrm{CH}_{2} \mathrm{Cl}_{2}$ dichloromethane/pentane $(80 \mathrm{~mL})$. The heterodimer product was converted to Weinreb amide derivative (+)-3a prior to isolation due to the volatile nature of the heterodimer. The resulting solution (from plug column) was concentrated to about $7 \mathrm{~mL}$ and then $\mathrm{N}, \mathrm{O}$-dimethylhydroxylamine ( $89 \mathrm{mg}, 1.46 \mathrm{mmol}$ ) was added, followed by 2-pyridone ( $4 \mathrm{mg}, 0.04 \mathrm{mmol}$ ) and the reaction was stirred for $3 \mathrm{~h}$ at room temperature. The reaction was quenched by the addition of water $(5 \mathrm{~mL})$, the layers were separated and the aqueous layer was extracted with $\mathrm{CH}_{2} \mathrm{Cl}_{2}$ dichloromethane $(2 \times 5 \mathrm{~mL})$. The combined organics were dried over $\mathrm{Na}_{2} \mathrm{SO}_{4}$, concentrated and purified by column chromatography over neutral silica to afford (+)-3a as a colorless oil (107 mg, 79\%); HPLC analysis: 91\% ee [Daicel Chiralpak AS-H column; $1 \mathrm{~mL} / \mathrm{min}$; solvent system: 2\% isopropanol in hexane; retention times: $13.3 \mathrm{~min}$ (minor), $16.7 \mathrm{~min}$ (major)]; $[\alpha]_{D}^{23}=31.6\left(\mathrm{c}=1.85, \mathrm{CH}_{2} \mathrm{Cl}_{2}\right.$ ); IR (thin film) 1713, $1656 \mathrm{~cm}^{-1},{ }^{1} \mathrm{H}$ NMR (400 MHz, CDCl, $\left.\mathrm{TMS}\right): \delta 3.91$ (q, J $7.1 \mathrm{~Hz}, 1 \mathrm{H}$ ), $3.64(\mathrm{~s}, 3 \mathrm{H}$ ), $3.18(\mathrm{~s}, 3 \mathrm{H}$ ), 
2.81-2.71 (m, 1H), 1.30 (d, J 7.1 Hz, 3H), 1.09 (d, J $6.8 \mathrm{~Hz}, 3 \mathrm{H}), 1.07$ (d, J $6.8 \mathrm{~Hz}, 3 \mathrm{H}) ;{ }^{13} \mathrm{C} \mathrm{NMR}\left(100 \mathrm{MHz}, \mathrm{CDCl}_{3}\right)$ : $\delta 210.5,172.2,61.3,48.7,39.2,32.7,18.9,18.7,13.4 ;\left(\mathrm{M}^{+}+\mathrm{Na}\right) \mathrm{HRMS} \mathrm{m} / z$ calcd for $\left(\mathrm{C}_{9} \mathrm{H}_{17} \mathrm{NO}_{3}\right)_{2} \mathrm{Na}_{3} 397.2309$; found: 397.2305 .

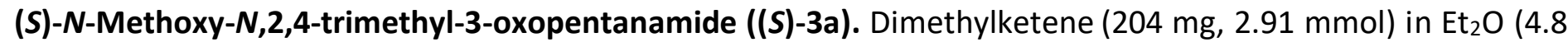
$\mathrm{mL}$ ) was added to a solution of Me-quinidine (98 mg, $0.29 \mathrm{mmol})$, and $\mathrm{LiClO}_{4}(155 \mathrm{mg}, 1.46 \mathrm{mmol})$ in $\mathrm{CH}_{2} \mathrm{Cl}_{2}(8.8$ $\mathrm{mL}$ ) and $\mathrm{Et}_{2} \mathrm{O}(2 \mathrm{~mL})$ at $-25^{\circ} \mathrm{C}$, and then Hünig's base (188 mg, $1.46 \mathrm{mmol}$ ) was added. Propionyl chloride (135 $\mathrm{mg}, 1.46 \mathrm{mmol})$ in $\mathrm{CH}_{2} \mathrm{Cl}_{2}(1 \mathrm{~mL})$ was added over $1 \mathrm{~h}$ to the above solution, and the mixture was stirred for $3 \mathrm{~h}$ at $-25^{\circ} \mathrm{C}$. The reaction was quenched by the addition of water $(5 \mathrm{~mL})$, the layers were separated and the aqueous layer was extracted with $\mathrm{CH}_{2} \mathrm{Cl}_{2}(2 \times 5 \mathrm{~mL})$. The combined organics were dried over anhydrous $\mathrm{Na}_{2} \mathrm{SO}_{4}$, and the solution was then concentrated to about $15 \mathrm{~mL}$ before being diluted with pentane $(15 \mathrm{~mL})$ and passed through a plug of neutral silica $(18 \mathrm{~g})$, eluting with $50 \% \mathrm{CH}_{2} \mathrm{Cl}_{2} /$ pentane $(180 \mathrm{~mL})$. The heterodimer product was converted to Weinreb amide derivative (-)-3a prior to isolation due to the volatile nature of the heterodimer. The solution (after plug column) was concentrated to about $10 \mathrm{~mL}$ and then $\mathrm{N}, \mathrm{O}$-dimethylhydroxylamine (178 $\mathrm{mg}, 1.46 \mathrm{mmol}$ ) was added, followed by 2-pyridone $(7 \mathrm{mg}, 0.07 \mathrm{mmol}$ ) and the reaction was stirred for $3 \mathrm{~h}$ at room temperature. The reaction was then quenched by the addition of water $(5 \mathrm{~mL})$, the layers were separated and the aqueous layer was extracted with $\mathrm{CH}_{2} \mathrm{Cl}_{2}(2 \times 5 \mathrm{~mL})$. The combined organics were dried over $\mathrm{Na}_{2} \mathrm{SO}_{4}$, the solution was concentrated and purified by column chromatography over neutral silica to afford (-)-3a as a colorless oil (244 mg, 89\%); HPLC analysis: 95\% ee [Daicel Chiralpak AS-H column; $1 \mathrm{~mL} / \mathrm{min}$; solvent system: $2 \%$ isopropanol in hexane; retention times: $12.7 \mathrm{~min}$ (major), $17.3 \mathrm{~min}$ (minor)]; $[\alpha]_{D}^{23}=-33.4\left(\mathrm{c}=1.45, \mathrm{CH}_{2} \mathrm{Cl}_{2}\right) ; \mathrm{IR}$ (thin film) 1713, $1656 \mathrm{~cm}^{-1} ;{ }^{1} \mathrm{H}$ NMR (400 MHz, CDCl, $\left.\mathrm{TMS}\right): \delta 3.91$ (q, J $\left.7.1 \mathrm{~Hz}, 1 \mathrm{H}\right), 3.64(\mathrm{~s}, 3 \mathrm{H}), 3.18(\mathrm{~s}, 3 \mathrm{H})$, 2.81-2.71 (m, $1 \mathrm{H}), 1.30(\mathrm{~d}, J 7.1 \mathrm{~Hz}, 3 \mathrm{H}), 1.09(\mathrm{~d}, J 6.8 \mathrm{~Hz}, 3 \mathrm{H}), 1.07(\mathrm{~d}, J 6.8 \mathrm{~Hz}, 3 \mathrm{H}) ;{ }^{13} \mathrm{C} \mathrm{NMR}\left(100 \mathrm{MHz}, \mathrm{CDCl}_{3}\right)$ : $\delta 210.5,172.2,61.3,48.7,39.2,32.7,18.9,18.7,13.4 ;\left(\mathrm{M}^{+}+\mathrm{Na}\right) \mathrm{HRMS} \mathrm{m} / z$ calcd for $\left(\mathrm{C}_{9} \mathrm{H}_{17} \mathrm{NO}_{3}\right)_{2} \mathrm{Na}_{3} 397.2309$; found: 397.2305 .

(R)-1-[Methoxy(methyl)amino]-4-methyl-1,3-dioxopentan-2-yl acetate ((R)-3b). Dimethylketene $(57 \mathrm{mg}, 0.81$ $\mathrm{mmol})$ in THF $(1.2 \mathrm{~mL})$ was added to a solution of Me-quinine $(27 \mathrm{mg}, 0.08 \mathrm{mmol})$ in $\mathrm{CH}_{2} \mathrm{Cl}_{2}(6 \mathrm{~mL})$ at room temperature, and then Hünig's base $(105 \mathrm{mg}, 0.81 \mathrm{mmol})$ was added. Acetoxyacetyl chloride $(110 \mathrm{mg}, 0.81$ $\mathrm{mmol})$ in $\mathrm{CH}_{2} \mathrm{Cl}_{2}(0.9 \mathrm{~mL})$ was added to the above solution at room temperature over $4 \mathrm{~h}$, and in the third hour of the addition the reaction was cooled down to $-25^{\circ} \mathrm{C}$. The reaction was stirred for $20 \mathrm{~h}$ at $-25^{\circ} \mathrm{C}$ and was then quenched by the addition of $\mathrm{HCl}(1 \mathrm{M}, 5 \mathrm{~mL})$. The layers were separated and the aqueous layer was extracted with $\mathrm{CH}_{2} \mathrm{Cl}_{2}(2 \times 5 \mathrm{~mL})$. The combined organics were washed with saturated sodium bicarbonate solution ( $5 \mathrm{~mL}$ ) and then dried over anhydrous $\mathrm{Na}_{2} \mathrm{SO}_{4}$. The heterodimer product was converted to Weinreb amide derivative (+)-3b prior to isolation due to the acid-sensitive nature of the heterodimer. N,O-Dimethylhydroxylamine (50 $\mathrm{mg}, 0.81 \mathrm{mmol}$ ) was added to the heterodimer solution, followed by 2-pyridone $(4 \mathrm{mg}, 0.04 \mathrm{mmol}$ ) and the reaction was stirred for $3 \mathrm{~h}$ at room temperature. The reaction was quenched by the addition of water $(5 \mathrm{~mL})$. The layers were separated and the aqueous layer was extracted with $\mathrm{CH}_{2} \mathrm{Cl}_{2}(2 \times 5 \mathrm{~mL})$. The combined organics were dried over anhydrous $\mathrm{Na}_{2} \mathrm{SO}_{4}$, concentrated and purified by column chromatography over neutral silica with a gradient elution (EtOAc/hexane 10 to 30\%) to afford (+)-3b as a colorless oil (98 mg, 52\%); HPLC analysis: 76\% ee [Daicel Chiralcel OD-H column; $1 \mathrm{~mL} / \mathrm{min}$; solvent system: $5 \%$ isopropanol in hexane; retention times: 11.7 min (major), 12.9 min (minor)]; $[\alpha]_{D}^{23}=8.6$ (c = 2.25, $\mathrm{CH}_{2} \mathrm{Cl}_{2}$ ); IR (thin film) 1755, 1727, $1672 \mathrm{~cm}^{-1} ;{ }^{1} \mathrm{H} \mathrm{NMR}$ $\left(400 \mathrm{MHz}, \mathrm{CDCl}_{3}, \mathrm{TMS}\right) \delta 6.00(\mathrm{~s}, 1 \mathrm{H}), 3.73(\mathrm{~s}, 3 \mathrm{H}), 3.21(\mathrm{~s}, 3 \mathrm{H}), 2.94-2.84(\mathrm{~m}, 1 \mathrm{H}), 1.11(\mathrm{~d}, J 6.8 \mathrm{~Hz}, 3 \mathrm{H}), 1.09(\mathrm{~d}$, J $6.8 \mathrm{~Hz}, 3 \mathrm{H}) ;{ }^{13} \mathrm{C}$ NMR $\left(100 \mathrm{MHz}, \mathrm{CDCl}_{3}\right): \delta 204.7,169.7,165.9,74.5,61.5,37.8,32.5,20.6,18.1,18.1 ;\left(\mathrm{M}^{+}+\mathrm{Na}\right)$ HRMS $m / z$ calcd for $\left(\mathrm{C}_{10} \mathrm{H}_{17} \mathrm{NO}_{5}\right)_{2} \mathrm{Na:} 485.2106$; found: 485.2103.

(S)-1-[Methoxy(methyl)amino]-4-methyl-1,3-dioxopentan-2-yl acetate ((S)-3b). Dimethylketene $(57 \mathrm{mg}, 0.81$ $\mathrm{mmol})$ in THF $(1.2 \mathrm{~mL})$ was added to a solution of Me-quinidine $(27 \mathrm{mg}, 0.08 \mathrm{mmol})$ in $\mathrm{CH}_{2} \mathrm{Cl}_{2}(6 \mathrm{~mL})$ at room 
temperature, and Hünig's base $(105 \mathrm{mg}, 0.81 \mathrm{mmol})$ was then added. Acetoxyacetyl chloride (110 mg, 0.81 $\mathrm{mmol})$ in $\mathrm{CH}_{2} \mathrm{Cl}_{2}(0.9 \mathrm{~mL})$ was added to the above solution at room temperature over $4 \mathrm{~h}$, and in the third hour of the addition the reaction was cooled down to $-25^{\circ} \mathrm{C}$. The reaction was stirred for $20 \mathrm{~h}$ at $-25^{\circ} \mathrm{C}$ and was then quenched by the addition of $\mathrm{HCl}(1 \mathrm{M}, 5 \mathrm{~mL})$. The layers were separated and the aqueous layer was extracted with $\mathrm{CH}_{2} \mathrm{Cl}_{2}(2 \times 5 \mathrm{~mL})$. The combined organics were washed with saturated sodium bicarbonate solution (5 mL) and then dried over anhydrous $\mathrm{Na}_{2} \mathrm{SO}_{4}$. The heterodimer product was converted to Weinreb amide derivative (-)-3b prior to isolation due to the acid-sensitive nature of the heterodimer. $\mathrm{N}, \mathrm{O}$-Dimethylhydroxylamine (50 $\mathrm{mg}, 0.81 \mathrm{mmol}$ ) was added to the heterodimer solution followed by 2 -pyridone $(4 \mathrm{mg}, 0.04 \mathrm{mmol})$ and the reaction was stirred for $3 \mathrm{~h}$ at room temperature. The reaction was quenched by the addition of water (5 mL). The layers were separated and the aqueous layer was extracted with $\mathrm{CH}_{2} \mathrm{Cl}_{2}(2 \times 5 \mathrm{~mL})$. The combined organics were dried over $\mathrm{Na}_{2} \mathrm{SO}_{4}$, concentrated and purified by column chromatography over neutral silica with a gradient elution (EtOAc/hexane 10 to 30\%) to afford (-)-3b as a colorless oil (106 mg, 57\%); HPLC analysis: 91\% ee [Daicel Chiralcel OD-H column; $1 \mathrm{~mL} / \mathrm{min}$; solvent system: $5 \%$ isopropanol in hexane; retention times: 12.0 $\min$ (minor), $12.8 \mathrm{~min}$ (major)]; $[\alpha]_{D}^{23}=-9.3$ (c=0.81, $\mathrm{CH}_{2} \mathrm{Cl}_{2}$ ); IR (thin film) 1755, 1727, $1672 \mathrm{~cm}^{-1} ;{ }^{1} \mathrm{H} \mathrm{NMR}(400$ $\left.\mathrm{MHz}_{\mathrm{CDCl}}, \mathrm{TMS}\right) \delta 6.00(\mathrm{~s}, 1 \mathrm{H}), 3.73(\mathrm{~s}, 3 \mathrm{H}), 3.21(\mathrm{~s}, 3 \mathrm{H}), 2.94-2.84(\mathrm{~m}, 1 \mathrm{H}), 1.11(\mathrm{~d}, J 6.8 \mathrm{~Hz}, 3 \mathrm{H}), 1.09(\mathrm{~d}, J 6.8$ $\mathrm{Hz}, 3 \mathrm{H}) ;{ }^{13} \mathrm{C} \mathrm{NMR}\left(100 \mathrm{MHz}, \mathrm{CDCl}_{3}\right): \delta 204.7,169.7,165.9,74.5,61.5,37.8,32.5,20.6,18.1,18.1 ;\left(\mathrm{M}^{+}+\mathrm{Na}\right) \mathrm{HRMS}$ $\mathrm{m} / \mathrm{z}$ calcd for $\left(\mathrm{C}_{10} \mathrm{H}_{17} \mathrm{NO}_{5}\right)_{2} \mathrm{Na}$ : 485.2106; found: 485.2103 .

$\mathbf{N}$-Methoxy-N,2-dimethyl-3-oxo-4-phenylpentanamide (3c). To the heterodimer (S)-2c (35.6 mg, $0.190 \mathrm{mmol})$ in THF $(0.8 \mathrm{~mL})$ was added 2-pyridone $(1 \mathrm{mg}, 0.01 \mathrm{mmol})$, followed by the addition of $\mathrm{N}, \mathrm{O}$ dimethylhydroxylamine $(23 \mathrm{mg}, 0.38 \mathrm{mmol}$ ). The reaction was then stirred for $3 \mathrm{~h}$ at room temperature. After 3 $h$ the reaction was quenched by the addition of water $(5 \mathrm{~mL})$, the layers were separated and the aqueous layer was extracted with $\mathrm{CH}_{2} \mathrm{Cl}_{2}(2 \times 5 \mathrm{~mL})$. The combined organics were dried over $\mathrm{Na}_{2} \mathrm{SO}_{4}$, and concentrated under reduced pressure. The resulting crude product was purified on a plug of neutral silica ( $5 \mathrm{~g})$, eluting with a gradient solvent system (EtOAc/hexane 5 to $50 \%$ ) to afford $3 \mathrm{c}$ as a colorless oil (40 mg, 84\%) with dr = 1.3:1 as determined by GC-MS analysis; ${ }^{1} \mathrm{H}$ NMR $\left(400 \mathrm{MHz}, \mathrm{CDCl}_{3}, \mathrm{TMS}\right)$ for mixture of diastereomers: $\delta$ 7.35-7.20 (m, $10 \mathrm{H}), 3.99-3.93(\mathrm{~m}, 2 \mathrm{H}), 3.83-3.75(\mathrm{~m}, 2 \mathrm{H}), 3.49(\mathrm{~s}, 6 \mathrm{H}), 3.13(\mathrm{~s}, 6 \mathrm{H}), 1.43-1.39(\mathrm{~m}, 6 \mathrm{H}), 1.34(\mathrm{~d}, J 7.3 \mathrm{~Hz}, 3 \mathrm{H})$, 1.16 (d, J 7.0 Hz, 3H); ${ }^{13} \mathrm{C} \mathrm{NMR}\left(100 \mathrm{MHz}, \mathrm{CDCl}_{3}\right): \delta 206.9,206.3,172.2,171.8,140.7,140.3,129.1,128.9,128.5$, $128.4,127.5,127.4,61.3,60.1,51.8,50.6,48.9,48.7,32.1,32.1,18.5,18.3,13.6,13.6$; MS (EI 70 eV): $\mathrm{m} / \mathrm{z} 249$ (13\%), 144 (26\%), 105 (100\%).

$\boldsymbol{N}$-Methoxy-N,2-dimethyl-3-oxo-4-phenylhexanamide (3d). To the heterodimer (S)-2d (35 $\mathrm{mg}, 0.17 \mathrm{mmol}$ ) in THF $(0.7 \mathrm{~mL})$ was added 2-pyridone $(1 \mathrm{mg}, 0.01 \mathrm{mmol})$, followed by the addition of $N, O$-dimethylhydroxylamine ( $21 \mathrm{mg}, 0.35 \mathrm{mmol}$ ). The reaction was then stirred for $3 \mathrm{~h}$ at room temperature. The reaction was quenched by the addition of water $(5 \mathrm{~mL})$, the layers were separated and the aqueous layer was extracted with $\mathrm{CH}_{2} \mathrm{Cl}_{2}(2 \times 5$ $\mathrm{mL}$ ). The combined organics were dried over $\mathrm{Na}_{2} \mathrm{SO}_{4}$, and concentrated under reduced pressure. The resulting crude product was purified on a plug of neutral silica $(5 \mathrm{~g})$, eluting with a gradient solvent system (EtOAc/hexane 5 to $30 \%$ ) to afford $3 d$ as a colorless oil (30 mg, 67\%) with $\mathrm{dr}=1.9: 1$ as determined by ${ }^{1} \mathrm{H}$ NMR analysis; ${ }^{1} \mathrm{H}$ NMR (400 MHz, $\left.\mathrm{CDCl}_{3}, \mathrm{TMS}\right)$ for mixture of diastereomers: $\delta 7.34-7.18(\mathrm{~m}, 10 \mathrm{H}), 3.83-3.69(\mathrm{~m}, 2 \mathrm{H}), 3.49(\mathrm{~s}, 6 \mathrm{H}), 3.10$ $(\mathrm{s}, 6 \mathrm{H}), 3.07-3.03(\mathrm{~m}, 2 \mathrm{H}), 2.12-2.02(\mathrm{~m}, 2 \mathrm{H}), 1.76-1.65(\mathrm{~m}, 2 \mathrm{H}), 1.35(\mathrm{~d}, J 7.6 \mathrm{~Hz}, 3 \mathrm{H}), 1.17(\mathrm{~d}, J 7.2 \mathrm{~Hz}, 3 \mathrm{H}), 0.83-$ 0.77 (m, 6H); MS (EI 70 eV): m/z 263 (24\%), 144 (37\%), 119 (71\%).

2-Methyl-3-oxo-2,4-diphenyl-pentanoic acid methoxy-methyl-amide (3e). Methylphenylketene homodimer $2 \mathrm{e}(117.7 \mathrm{mg}, 0.45 \mathrm{mmol})$ was dissolved in $\mathrm{CH}_{2} \mathrm{Cl}_{2}(2.23 \mathrm{~mL}, 0.2 \mathrm{M})$. After a few minutes the Weinreb amine (65 $\mu \mathrm{l}, 0.89 \mathrm{mmol})$ and the 2-pyridone $(4.2 \mathrm{mg}, 0.05 \mathrm{mmol})$ were added. The reaction was stirred for 4 days until TLC showed complete consumption of reactant and then the reaction was quenched with $\mathrm{H}_{2} \mathrm{O}(10 \mathrm{~mL})$, the layers were separated, and the aqueous phase was extracted with $\mathrm{CH}_{2} \mathrm{Cl}_{2}(3 \times 10 \mathrm{~mL})$, the combined organic 
layers were dried over anhydrous $\mathrm{Na}_{2} \mathrm{SO}_{4}$ and the solvent was removed under reduced pressure. The resulting crude product was purified by flash column chromatography on neutral silica (iatrobeads, $12.5 \mathrm{~g}$ ) using a gradient of solvents (EtOAc/hexane 5 to 15\%) to afford 3e as a solidifying colorless oil (106 mg, 72\%), isolated as an inseparable mixture of diastereomers, with a $\mathrm{dr}=1.4: 1$ as determined by GC-MS analysis; IR (thin film): $1714,1652,1180 \mathrm{~cm}^{-1} ;{ }^{1} \mathrm{H}$ NMR of the mixture of diastereomers $\left(200 \mathrm{MHz}, \mathrm{CDCl}_{3}, \mathrm{TMS}\right): \delta 7.31-6.86(\mathrm{~m}, 10 \mathrm{H})$, 4.02-3.89 (m, 1H), $3.16(\mathrm{~s}, 3 \mathrm{H}), 3.06(\mathrm{~s}, 1 \mathrm{H}), 3.04(\mathrm{~s}, 1 \mathrm{H}), 2.97(\mathrm{~s}, 1 \mathrm{H}), 1.71(\mathrm{~s}, 3 \mathrm{H}), 1.53(\mathrm{~s}, 3 \mathrm{H}), 1.32(\mathrm{~d}, J 6.8 \mathrm{~Hz}$, 3H), 1.30 (d, J $6.8 \mathrm{~Hz}, 3 \mathrm{H}) ;{ }^{13} \mathrm{C}$ NMR $\left(50 \mathrm{MHz} \mathrm{CDCl}_{3}\right): \delta 207.4,206.9,141.7,141.2,139.6,138.6,128.7,128.4$, $128.3,128.1,128.1,127.8,127.6,127.2,127.0,126.6,64.5,64.2,59.9,59.6,50.1,49.3,33.6,23.1,21.9,21.7$, 21.5; MS (EI 70 eV): m/z 325 (1\%), 193 (99\%), 162 (45\%), 132 (17\%), 105 (100\%), 77 (16\%); (M+ + Na) HRMS m/z calcd for $\mathrm{C}_{20} \mathrm{H}_{23} \mathrm{NO}_{3} \mathrm{Na}$ : 348.1570; found: 348.1564.

$(\boldsymbol{R}, Z)$-3-Hexyl-4-[(trimethylsilyl)methylene]oxetan-2-one ((-)-2f). Octanoyl chloride (199.75.1 mg, $1.23 \mathrm{mmol})$ in $\mathrm{CH}_{2} \mathrm{Cl}_{2}(1.0 \mathrm{~mL})$ and Hünig's base $(158.8 \mathrm{mg}, 1.23 \mathrm{mmol})$ in $\mathrm{CH}_{2} \mathrm{Cl}_{2}(1.0 \mathrm{~mL})$ were added over $12 \mathrm{~h}$ to a solution of TMS-ketene $(280.1 \mathrm{mg}, 2.46 \mathrm{mmol})$ and TMS-quinine $(97.4 \mathrm{mg}, 0.25 \mathrm{mmol})$ in $\mathrm{CH}_{2} \mathrm{Cl}_{2}(3.0 \mathrm{~mL})$ at $-25^{\circ} \mathrm{C}$. The reaction was stirred at this temperature for $16 \mathrm{~h}$ and it was then diluted with pentane $(15 \mathrm{~mL})$ and $20 \%$ $\mathrm{CH}_{2} \mathrm{Cl}_{2}$ /pentane $(15 \mathrm{~mL}$ ), before being passed through a plug of neutral silica $(28 \mathrm{~g}$ ), eluting with $20 \%$ $\mathrm{CH}_{2} \mathrm{Cl}_{2}$ /pentane. The solvent was removed under reduced pressure and (-)-2f was isolated as a colorless oil (163.3 mg, 55\%); HPLC analysis was performed on the Weinreb amide $\mathbf{3 f}$ derived from 2f: $97 \%$ ee [Daicel Chiralcel OD-H column; $1 \mathrm{~mL} / \mathrm{min}$; solvent system: $10 \%$ isopropanol in hexane; retention times: 3.4 min (minor),

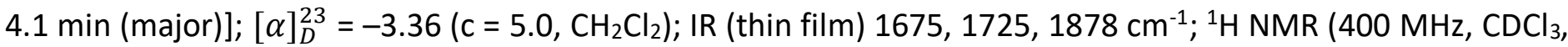
TMS): $\delta 4.66(\mathrm{~d}, J 1.2 \mathrm{~Hz}, 1 \mathrm{H}), 3.95(\mathrm{dt}, J 1.2,7.2 \mathrm{~Hz}, 1 \mathrm{H}), 1.79(\mathrm{q}, J 7.6 \mathrm{~Hz}, 2 \mathrm{H}), 1.70-1.24(\mathrm{~m}, 8 \mathrm{H}), 0.90(\mathrm{t}, J 6.4$ $\mathrm{Hz}, 3 \mathrm{H}) 0.16(\mathrm{~s}, 9 \mathrm{H}) ;{ }^{13} \mathrm{C} \mathrm{NMR}\left(100 \mathrm{MHz}, \mathrm{CDCl}_{3}\right): \delta 170.2,157.6,96.8,56.11,31.7,29.1,27.5,26.4,22.7,14.2,-$ $0.3 ;\left(\mathrm{M}^{+}+\mathrm{H}\right) \mathrm{HRMS} \mathrm{m} / \mathrm{z}$ calcd for $\left(\mathrm{C}_{13} \mathrm{H}_{24} \mathrm{O}_{2} \mathrm{Si}\right) \mathrm{H}$ : 241.1618; found: 241.1618 .

(R)-O-Benzyl serine allyl ester (4). To a suspension of $O$-benzyl-D-serine $(1.19 \mathrm{~g}, 6.12 \mathrm{mmol})$ in distilled $\mathrm{MeOH}$ $(22 \mathrm{~mL})$ was added triethylamine $(1.01 \mathrm{~mL}, 7.96 \mathrm{mmol})$ and $p$-anisaldehyde $(1.25 \mathrm{~g}, 9.18 \mathrm{mmol})$ at $23^{\circ} \mathrm{C}$. The resulting suspension was stirred until the solution became homogeneous ( $30 \mathrm{~min}$ ). The solution was then cooled to $0{ }^{\circ} \mathrm{C}$, followed by addition of anhydrous $\mathrm{MgSO}_{4}(3.7 \mathrm{~g}, 30.8 \mathrm{mmol})$. After $7 \mathrm{~h}$, the $\mathrm{MgSO}_{4}$ was filtered via fritted funnel and washed with $\mathrm{MeOH}(40 \mathrm{~mL})$. The combined filtrate was cooled to $0{ }^{\circ} \mathrm{C}$ for $15 \mathrm{~min}$ and then $\mathrm{NaBH}_{4}(300 \mathrm{mg}, 7.96 \mathrm{mmol})$ was added portionwise. After stirring at $0{ }^{\circ} \mathrm{C}$ for $2 \mathrm{~h}$, the solidified reaction mixture was left in a freezer $\left(\sim-10^{\circ} \mathrm{C}\right)$ for $12 \mathrm{~h}$. All volatiles were removed under reduced pressure and the remaining solid was resuspended in water $(15 \mathrm{~mL})$ and acidified to $\mathrm{pH} 3$ with $2 \mathrm{~N} \mathrm{HCl}$. The precipitated colorless solid was filtered via a Büchner funnel, washed with ice-cold water $(2 \times 10 \mathrm{~mL})$ and ice-cold $\mathrm{Et}_{2} \mathrm{O}(2 \times 10 \mathrm{~mL})$, and dried under vacuum to give $O$-benzyl- $N$-PMB serine as a colorless solid. To $O$-benzyl- $N$-PMB serine $(2.04 \mathrm{~g}, 6.47 \mathrm{mmol})$ and $p$ - TsOH (1.34 g, $7.76 \mathrm{mmol})$ was added allyl alcohol $(6 \mathrm{~mL})$ and toluene $(40 \mathrm{~mL})$. The solution was stirred at reflux $\left(\sim 124^{\circ} \mathrm{C}\right.$ ) over molecular sieves for $\sim 8 \mathrm{~h}$. The resulting solution was concentrated, resuspended in $5 \%$ aqueous $\mathrm{NaHCO}_{3}(36 \mathrm{~mL})$, and extracted with EtOAc $(150 \mathrm{~mL}$ ). The $\mathrm{pH}$ was adjusted to 10.0 (until pH of aqueous solution maintained at 10 after extraction) with $2 \mathrm{M} \mathrm{NaOH}$ solution. The organic layer was washed with brine, dried over $\mathrm{MgSO}_{4}$, and concentrated under reduced pressure. The residue was purified by flash column chromatography (20\% EtOAc/hexanes) on silica to give the desired allyl ester 4 (907 $\mathrm{mg}, 42 \%)$ as a yellow oil. $[\alpha]_{D}^{23}=+21.3\left(c=1.8, \mathrm{CHCl}_{3}\right) ;{ }^{1} \mathrm{H}$ NMR $\left(400 \mathrm{MHz}, \mathrm{CDCl}_{3}\right) \delta 7.23-7.32(\mathrm{~m}, 8 \mathrm{H}), 6.84(\mathrm{~d}, \mathrm{~J} 4.8 \mathrm{~Hz}, 2 \mathrm{H}), 5.86-5.93$ $(\mathrm{m}, 1 \mathrm{H}), 5.22-5.34(\mathrm{~m}, 2 \mathrm{H}), 4.64(\mathrm{~d}, J 2.4 \mathrm{~Hz} 2 \mathrm{H}), 4.63$ (d, J $2.4 \mathrm{~Hz} 3 \mathrm{H}), 3.83$ (d, J $12.8 \mathrm{~Hz} 1 \mathrm{H}), 3.71-3.74(\mathrm{~m}, 3$ $\mathrm{H}), 3.65-3.64(\mathrm{~m}, 3 \mathrm{H}), 3.51(\mathrm{t}, J 4.8 \mathrm{~Hz} 1 \mathrm{H}) ;{ }^{13} \mathrm{C} \mathrm{NMR}\left(400 \mathrm{MHz}, \mathrm{CDCl}_{3}\right) \delta 173.1,159.0,138.1,132.2,132.0,129.7$ (2C), $128.6(2 \mathrm{C}), 127.9,127.8(2 \mathrm{C}), 118.7,114.0(2 \mathrm{C}), 73.5,71.4,65.7,60.7,55.5,51.6$.

(R)-Allyl 2-[(R)-2-acetyl-N-(4-methoxybenzyl)octanamido]-3-(benzyloxy)propanoate (5). (-)-2f (26.5 mg, 0.11 $\mathrm{mmol}$ ), serine derivative 4 (82 $\mathrm{mg}, 0.22 \mathrm{mmol})$, 2-pyridone $(21 \mathrm{mg}, 0.22 \mathrm{mmol})$, and acetic acid $(6.6 \mathrm{mg}, 0.11$ 
$\mathrm{mmol})$ were dissolved in THF $(0.8 \mathrm{~mL})$ and stirred at room temperature. $\mathrm{KF}(10.4 \mathrm{mg}, 0.11 \mathrm{mmol})$ was then added and after stirring at room temperature for $15 \mathrm{~min}$ the solution then was heated to $50{ }^{\circ} \mathrm{C}$ for $55 \mathrm{~h}$. After this time, the reaction was cooled to room temperature and water $(5 \mathrm{~mL})$ was added. The layers were separated and the aqueous layer was extracted with $\mathrm{CH}_{2} \mathrm{Cl}_{2}(3 \times 5 \mathrm{~mL})$. The combined organic layers were dried over anhydrous $\mathrm{Na}_{2} \mathrm{SO}_{4}$ and the solvent was removed under reduced pressure. The crude product was purified by column chromatography using gradient elution (EtOAc/hexane, 10 to 15\%) to afford 5 as a colorless oil (9.1 mg, 16\%) with a $\mathrm{dr}=49: 1$ as determined by ${ }^{1} \mathrm{H}$ NMR; $[\alpha]_{D}^{23}=25.5$ (c=0.9 mg/mL, $\mathrm{CH}_{2} \mathrm{Cl}_{2}$ ); IR (thin film): 1737, 1645, 2165 $\mathrm{cm}^{-1}$; ${ }^{1} \mathrm{H}$ NMR $\left(400 \mathrm{MHz} \mathrm{CDCl}_{3}, \mathrm{TMS}\right): \delta 7.34-7.14(\mathrm{~m}, 9 \mathrm{H}), 6.85(\mathrm{~d}, J 8.8 \mathrm{~Hz}, 2 \mathrm{H}), 5.93-5.83(\mathrm{~m}, 1 \mathrm{H}), 5.33-5.22(\mathrm{~m}$, $2 \mathrm{H}), 4.83(\mathrm{~d}, J 17.2,1 \mathrm{H}), 4.66-4.54(\mathrm{~m}, 4 \mathrm{H}), 4.40(\mathrm{~d}, J 3.2,2 \mathrm{H}), 4.04-3.92(\mathrm{~m}, 2 \mathrm{H}), 3.80(\mathrm{~s}, 3 \mathrm{H}), 3.51(\mathrm{dd}, J 5.6,8.0$ $\mathrm{Hz}, 1 \mathrm{H}), 2.12(\mathrm{~s}, 3 \mathrm{H}), 2.03-2.91(\mathrm{~m}, 1 \mathrm{H}), 1.72-1.65(\mathrm{~m}, 1 \mathrm{H}), 1.35-1.24(\mathrm{~m}, 6 \mathrm{H}), 0.85(\mathrm{t}, J 6.8,3 \mathrm{H}) ;{ }^{13} \mathrm{C} \mathrm{NMR}(50$ $\mathrm{MHz}_{\mathrm{CDCl}}$ ): $\delta 205.3,170.7,168.7,159.4,137.9,132.0,128.9,128.6,128.3,127.9,127.8,118.9,114.3,73.6$, 68.7, 66.2, 59.9, 59.0, 55.5, 51.8, 31.7, 29.8, 29.2, 27.7, 27.1, 22.8, 14.2; $\left(\mathrm{M}^{+}+\mathrm{H}\right) \mathrm{HRMS} \mathrm{m} / \mathrm{z}$ cacld for $\left(\mathrm{C}_{31} \mathrm{H}_{41} \mathrm{NO}_{6}\right) \mathrm{H}: 524.3007$; found: 524.3003 .

A procedure which provides 5 in $82 \%$ yield but with moderate dr of 3:1 was previously reported by our group. ${ }^{20}$ 3,5,5-Trimethyl-6-phenyldihydro-2H-pyran-2,4(3H)-dione (6a). 2-Bromo-2-methylpropionyl bromide (372 mg, $1.60 \mathrm{mmol}$ ) was added to zinc dust $(280 \mathrm{mg}, 4.30 \mathrm{mmol})$ in $\mathrm{Et}_{2} \mathrm{O}(2.4 \mathrm{~mL})$ at $-78^{\circ} \mathrm{C}$, stirred for $10 \mathrm{~min}$ at $-78^{\circ} \mathrm{C}$, and then was warmed up to $0{ }^{\circ} \mathrm{C}$ and was stirred for $20 \mathrm{~min}$ at $0{ }^{\circ} \mathrm{C}$. The ketene and ether were then vacuum transferred to the collection flask dipped in liquid nitrogen. The frozen solution was melted at $-78^{\circ} \mathrm{C}$ to afford a yellow solution of ketene. The above obtained dimethylketene $(102 \mathrm{mg}, 1.46 \mathrm{mmol})$ in $\mathrm{Et}_{2} \mathrm{O}(2.4 \mathrm{~mL}) \mathrm{was}$ added to a solution of Me-quinidine (50 mg, $0.15 \mathrm{mmol}$ ), and $\mathrm{LiClO}_{4}\left(155 \mathrm{mg}, 1.46 \mathrm{mmol}\right.$ ) in $\mathrm{CH}_{2} \mathrm{Cl}_{2}(4.4 \mathrm{~mL})$ and $\mathrm{Et}_{2} \mathrm{O}(1 \mathrm{~mL})$ at $-25^{\circ} \mathrm{C}$. Hünig's base $(94 \mathrm{mg}, 0.73 \mathrm{mmol})$ was then added. Propionyl chloride $(67 \mathrm{mg}, 0.73 \mathrm{mmol})$ in $\mathrm{CH}_{2} \mathrm{Cl}_{2}(0.5 \mathrm{~mL})$ was added over $1 \mathrm{~h}$ to the above solution, the mixture was stirred for $3 \mathrm{~h}$ at $-25^{\circ} \mathrm{C}$ and then the reaction was quenched by the addition of water $(5 \mathrm{~mL})$. The layers were separated and the aqueous layer was washed with $\mathrm{CH}_{2} \mathrm{Cl}_{2}(3 \times 5 \mathrm{~mL})$. The combined organics were dried over anhydrous $\mathrm{Na}_{2} \mathrm{SO}_{4}$ and then concentrated under reduced pressure to about $10 \mathrm{~mL}$. The solution was diluted with pentane $(10 \mathrm{~mL})$ and passed through a plug of neutral silica ( $10 \mathrm{~g}$ ), eluting with $50 \% \mathrm{CH}_{2} \mathrm{Cl}_{2} /$ pentane $(80 \mathrm{~mL})$. The solvent was removed under reduced pressure to obtain the crude heterodimer (S)-2a (89 $\mathrm{mg}, 97 \%$ ). To a solution of $\mathrm{N}, \mathrm{O}$ dimethylhydroxylamine $(32 \mu \mathrm{L}, 0.43 \mathrm{mmol})$ in THF $(2.1 \mathrm{~mL})$ at $-78{ }^{\circ} \mathrm{C}$ was added dropwise $n$-BuLi $(2.5 \mathrm{M}$ in hexanes, $1.17 \mathrm{~mL}, 0.41 \mathrm{mmol}$ ), and the solution was stirred for $30 \mathrm{~min}$. After $30 \mathrm{~min}$, this solution was added to crude heterodimer $(S)-2 a(52.2 \mathrm{mg}, 0.410 \mathrm{mmol})$ in $\mathrm{THF}$ at $-78^{\circ} \mathrm{C}$. The reaction mixture was stirred for another $30 \mathrm{~min}$ at $-78{ }^{\circ} \mathrm{C}$ and then benzaldehyde $(127 \mu \mathrm{L}, 1.31 \mathrm{mmol})$ was added neat. After $40 \mathrm{~min}$ of stirring at -78 ${ }^{\circ} \mathrm{C}$, the reaction flask was allowed to warm up for $30 \mathrm{~min}$ at room temperature. The reaction was quenched by the addition of $\mathrm{NH}_{4} \mathrm{Cl}(5 \mathrm{~mL})$. The aqueous phase was extracted with $\mathrm{CH}_{2} \mathrm{Cl}_{2}(3 \times 5 \mathrm{~mL})$, and the combined organic layers were dried over anhydrous $\mathrm{Na}_{2} \mathrm{SO}_{4}$ and filtered. The solvent was removed under reduced pressure. The resulting crude product was purified on a plug of neutral silica (iatrobeads), eluting with a gradient solvent system (EtOAc/hexane, 5 to 50\%). The solvent was removed under reduced pressure to afford $\delta$-lactone $6 \mathbf{a}$ (38 $\mathrm{mg}, 40 \%$ ) as a colorless solid with $\mathrm{dr}=24: 1$ as determined by ${ }^{1} \mathrm{H}$ NMR analysis; GC analysis: $40 \%$ ee [Supelco Chiraldex B-DM column; GC Conditions: Split ratio: 20; make up flow: $25 \mathrm{~mL} / \mathrm{min}$; $\mathrm{H}_{2}$ flow: $45 \mathrm{~mL} / \mathrm{min}$; air flow: $450 \mathrm{~mL} / \mathrm{min}$; injector temperature: $250{ }^{\circ} \mathrm{C}$, pressure: $15 \mathrm{psi}$; oven temperature: $80^{\circ} \mathrm{C}$; detector temperature:

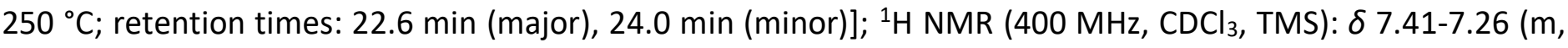
$5 \mathrm{H}), 5.56(\mathrm{~s}, 1 \mathrm{H}), 3.79(\mathrm{q}, J 6.6 \mathrm{~Hz}, 1 \mathrm{H}), 1.43(\mathrm{~d}, J 6.6 \mathrm{~Hz}, 3 \mathrm{H}), 1.10(\mathrm{~s}, 3 \mathrm{H}), 0.94(\mathrm{~s}, 3 \mathrm{H}) ;{ }^{13} \mathrm{C} \mathrm{NMR}\left(100 \mathrm{MHz}, \mathrm{CDCl}_{3}\right)$ : $\delta$ 207.2, 169.7, 133.6, 129.1, 128.3, 127.9, 83.5, 49.3, 48.0, 21.6, 18.4, 8.5; MS (El 70 eV): $\mathrm{m} / \mathrm{z} 232$ (2\%), 126 (49\%), 70 (100\%). 
3,5-Dimethyl-3,5,6-triphenyldihydro-2H-pyran-2,4(3H)-dione (6e). $\mathrm{MeOH}(23 \mu \mathrm{L}, 0.56 \mathrm{mmol})$ was dissolved in THF $(3.0 \mathrm{~mL})$ and cooled to $0{ }^{\circ} \mathrm{C}$. $n$-BuLi $(2.5 \mathrm{M}$ in hexanes, $224 \mu \mathrm{L}, 0.56 \mathrm{mmol})$, was then slowly added to the stirred solution of $\mathrm{MeOH}$ in $\mathrm{THF}$ at $0{ }^{\circ} \mathrm{C}$. After the addition was complete, the solution was stirred for a further $15 \mathrm{~min}$ at $0^{\circ} \mathrm{C}$ to ensure generation of MeOLi. Methylphenylketene homodimer $2 \mathrm{e}(148 \mathrm{mg}, 0.56 \mathrm{mmol})$ was dissolved in THF $(1.5 \mathrm{~mL})$, and added slowly to the MeOLi solution at $0{ }^{\circ} \mathrm{C}$. The reaction solution was stirred for a further $45 \mathrm{~min}$ at $0^{\circ} \mathrm{C}$, before the reaction was allowed to warm to room temperature and stirred for a further $2 \mathrm{~h}$ at room temperature. The reaction solution was then cooled to $-78^{\circ} \mathrm{C}$ and benzaldehyde $(85 \mu \mathrm{L}, 0.84 \mathrm{mmol}$, 1.5 equiv) was added to the solution. The reaction was then allowed to warm to room temperature and stirred for a further $5 \mathrm{~h}$ at room temperature. After this time, the reaction was diluted with $\mathrm{CH}_{2} \mathrm{Cl}_{2}(10 \mathrm{~mL})$, and quenched by addition of saturated ammonium chloride solution $(10 \mathrm{~mL})$. The layers were separated, the aqueous layer was extracted with $\mathrm{CH}_{2} \mathrm{Cl}_{2}(3 \times 10 \mathrm{~mL})$, and the combined organics were dried over anhydrous $\mathrm{Na}_{2} \mathrm{SO}_{4}$. The solvent was removed in vacuo to provide the crude product (182 $\left.\mathrm{mg}, 88 \%\right)$ for GC-MS and ${ }^{1} \mathrm{H}$ NMR analysis. The resulting crude product was purified by flash column chromatography on neutral silica (iatrobeads, $18 \mathrm{~g}$ ), using a gradient solvent system (from hexane to 1-5\% EtOAc/hexane). The solvent was removed under reduced pressure to provide the desired product $6 \mathrm{e}(97 \mathrm{mg}, 47 \%)$ as an oil with a $\mathrm{dr}=9: 1$ as determined by GCMS analysis; ${ }^{1} \mathrm{H}$ NMR (200 MHz, $\left.\mathrm{CDCl}_{3}, \mathrm{TMS}\right): \delta$ 7.41-6.99 (m, 10H), 6.60-6.56 (m, 5H), $5.61(\mathrm{~s}, 1 \mathrm{H}), 1.73(\mathrm{~s}, 3 \mathrm{H})$, 1.36 (s, 3H); MS (EI $70 \mathrm{eV}): \mathrm{m} / z 370$ (1\%), 264 (33\%), $132(100 \%) ;\left(\mathrm{M}^{+}+\mathrm{Na}\right) \mathrm{HRMS} \mathrm{m} / z$ calcd for $\mathrm{C}_{25} \mathrm{H}_{22} \mathrm{O}_{3} \mathrm{Na}$ : 393.1461; found: 393.1456.

2-Methyl-3-oxo-2,4-diphenyl-pentanoic acid methyl ester (8e). $0.2 \mathrm{ml}$ of $n$-BuLi (2.5 $\mathrm{M}$ in hexane) was added to a stirred solution of $\mathrm{MeOH}(2.06 \mathrm{mmol}, 83 \mu \mathrm{L})$ in THF $(1.85 \mathrm{~mL})$ at $0{ }^{\circ} \mathrm{C}$ and stirred for $10 \mathrm{~min}$. Methylphenylketene homodimer $2 \mathrm{e}(136.0 \mathrm{mg}, 0.51 \mathrm{mmol})$ was dissolved in THF $(5 \mathrm{~mL})$ and the solution was now added dropwise to the solution of MeOLi at $0{ }^{\circ} \mathrm{C}$. The reaction was stirred for 85 min until TLC showed complete consumption of reactant. Then the reaction was quenched with $\mathrm{HCl}(1 \mathrm{M}, 10 \mathrm{~mL})$ and the layers were separated. The aqueous layer was extracted with $\mathrm{CH}_{2} \mathrm{Cl}_{2}(3 \times 10 \mathrm{~mL})$, and the combined organics were dried over $\mathrm{Na}_{2} \mathrm{SO}_{4}$. The solvent was removed under reduced pressure. The resulting product $8 \mathrm{e}$ was obtained quantitatively as a colorless oil, isolated as an inseparable mixture of diastereomers, with a $\mathrm{dr}=1.6: 1$ as determined by GC-MS analysis. IR (thin film): 1716, 1251, $1208 \mathrm{~cm}^{-1}$; ${ }^{1} \mathrm{H}$ NMR of the mixture of diastereomers $\left(200 \mathrm{MHz}, \mathrm{CDCl}_{3}, \mathrm{TMS}\right): \delta 7.26-6.99(\mathrm{~m}, 8 \mathrm{H}), 6.83-6.78(\mathrm{~m}, 2 \mathrm{H}), 3.95(\mathrm{q}, J 7.0 \mathrm{~Hz}, 1 \mathrm{H}), 3.85(\mathrm{q}, J 6.8 \mathrm{~Hz}, 1 \mathrm{H}), 3.71$ $(\mathrm{s}, 3 \mathrm{H}), 3.42(\mathrm{~s}, 3 \mathrm{H}), 1.66(\mathrm{~s}, 3 \mathrm{H}), 1.61(\mathrm{~s}, 3 \mathrm{H}), 1.31(\mathrm{~d}, J 7.0 \mathrm{~Hz}, 3 \mathrm{H}), 1.24(\mathrm{~d}, J 7.0 \mathrm{~Hz}, 3 \mathrm{H}) ;{ }^{13} \mathrm{C}$ NMR for the mixture of diastereomers $\left(50 \mathrm{MHz}, \mathrm{CDCl}_{3}\right): \delta 208.2,207.5,172.9,172.3,141.4,138.3,137.5,128.6,128.5,128.1,128.0$, 128.0, 127.5, 127.0, 126.7, 65.5, 65.4, 52.7, 52.5, 49.7, 49.5, 29.9, 22.4, 22.2, 21.9, 21.5; MS (El 70 eV): $\mathrm{m} / \mathrm{z} 296$ (1\%), 164 (37\%), 132 (10\%), 105 (100\%), 77 (11\%); $\left(\mathrm{M}^{+}+\mathrm{Na}\right)$ HRMS m/z calcd for $\mathrm{C}_{19} \mathrm{H}_{20} \mathrm{O}_{3} \mathrm{Na:} 319.1305$; found: 319.1298.

\section{Acknowledgements}

Support has been provided by the National Science Foundation and the National Institutes of Health: Grant Nos. CHE-1463728 to N.J.K. and R15GM107800 to N.J.K.

\section{Supplementary Material}

Electronic Supplementary Information available: spectra for amides 3a-3e and 5, and $\delta$-lactones 6a and 6e. 


\section{References}

1. Sauer, J. C. J. Am. Chem. Soc. 1947, 69, 2444-2448. https://doi.org/10.1021/ja01202a058

2. Hasek, R. H.; Clark, R. D.; Elam, E. U.; Martin, J. C. J. Org. Chem. 1962, 27, 60-64. https://doi.org/10.1021/jo01048a015

3. Elam, E. U. J. Org. Chem. 1967, 32, 215-216. https://doi.org/10.1021/jo01277a053

4. Bentrude, W. G.; Johnson, W. D. J. Am. Chem. Soc. 1968, 90, 5924-5926. https://doi.org/10.1021/ja01023a062

5. Aronov, Y. E.; Cheburkov, Y. A.; Knunyants, I. L. Izv. Akad. Nauk SSSR, Ser. Khim. 1967, 8, 1758-1768.

6. Moore, H. W.; Duncan, W. G. J. Org. Chem. 1973, 38, 156-158. https://doi.org/10.1021/jo00941a036

7. Calter, M. A. J. Org. Chem. 1996, 61, 8006-8007. https://doi.org/10.1021/jo961721c

8. Calter, M. A.; Orr, R. K. Org. Lett. 2003, 5, 4745-4748. https://doi.org/10.1021/ol0359517

9. Calter, M. A.; Guo, X. J. Org. Chem. 1998, 63, 5308-5309. https://doi.org/10.1021/jo9808977

10. Calter, M. A.; Guo, X.; Liao, W. Org. Lett. 2001, 3, 1499-1501. https://doi.org/10.1021/ol015814e

11. Calter, M. A.; Liao, W.; Struss, J. A. J. Org. Chem. 2001, 66, 7500-7504. https://doi.org/10.1021/jo0160367

12. Calter, M. A.; Liao, W. J. Am. Chem. Soc. 2002, 124, 13127-13129. https://doi.org/10.1021/ja027675h

13. Calter, M. A.; Song, W.; Zhou, J. J. Org. Chem. 2004, 69, 1270-1275. https://doi.org/10.1021/jo0356681

14. Purohit, V. C.; Richardson, R. D.; Smith, J. W.; Romo, D. J. Org. Chem. 2006, 71, 4549-4558. https://doi.org/10.1021/jo060392d

15. Ma, G.; Nguyen, H.; Romo, D. Org. Lett. 2007, 9, 2143-2146. https://doi.org/10.1021/ol070616u

16. Nguyen, H.; Ma, G.; Romo, D. Chem. Commun. 2010, 46, 4803-4805. https://doi.org/10.1039/c0cc00607f

17. Ibrahim, A. A.; Harzmann, G. D.; Kerrigan, N. J. J. Org. Chem. 2009, 74, 1777-1780. https://doi.org/10.1021/jo8024785

18. Ibrahim, A. A.; Wei, P.-H.; Harzmann, G. D.; Kerrigan, N. J. J. Org. Chem. 2010, 75, 7901-7904. https://doi.org/10.1021/jo101867m

19. Ibrahim, A. A.; Nalla, D.; Van Raaphorst, M.; Kerrigan, N. J. J. Am. Chem. Soc. 2012, 134, 2942-2945. https://doi.org/10.1021/ja211678m

20. Chen, S.; Ibrahim, A. A.; Peraino, N. J.; Nalla, D.; Mondal, M.; Van Raaphorst, M.; Kerrigan, N. J. J. Org. Chem. 2016, 81, 7824-7837.

https://doi.org/10.1021/acs.joc.6b01481

21. Ibrahim, A. A.; Smith, S. M.; Henson, S.; Kerrigan, N. J. Tetrahedron Lett. 2009, 50, 6919-6922. https://doi.org/10.1016/j.tetlet.2009.09.158 
22. Wei, P.-H.; Gary, M. A.; Nalla, D.; Harzmann, G. D.; Ibrahim, A. A.; Dayak, K. R.; Kerrigan, N. J. Tetrahedron Lett. 2013, 54, 932-935.

https://doi.org/10.1016/j.tetlet.2012.12.011

23. Salo, E. C.; Dayak, K. R.; Huxford, J.; Wei, P.-H.; Peraino, N. J.; Kerrigan, N. J. ARKIVOC 2014, iv, 285-295. https://doi.org/10.3998/ark.5550190.p008.443

24. Chen, S.; Ibrahim, A. A.; Mondal, M.; Magee, A. J.; Cruz, A. J.; Wheeler, K. A.; Kerrigan, N. J. Org. Lett. 2015, $17,3248-3251$.

https://doi.org/10.1021/acs.orglett.5b01391

25. Chen, S.; Mondal, M.; Ibrahim, A. A.; Wheeler, K. A.; Kerrigan, N. J. Synthesis 2016, 48, 2619-2626. https://doi.org/10.1055/s-0035-1561958

26. Panda, M.; Mondal, M.; Chen, S.; Ibrahim, A. A.; Twardy, D. J.; Kerrigan, N. J. Eur. J. Org. Chem. 2020, 57525764.

https://doi.org/10.1002/ejoc.202000976

27. Mondal, M. ; Chen, S.; Othman, N.; Wheeler, K. A.; Kerrigan, N. J. J. Org. Chem. 2015, 80, 5789-5794. https://doi.org/10.1002/ejoc.202000976

28. Häner, R.; Laube, T.; Seebach, D. J. Am. Chem. Soc. 1985, 107, 5396-5403. https://doi.org/10.1021/ja00305a013

29. Yamago, S.; Machii, D.; Nakamura, E. J. Org. Chem. 1991, 56, 2098-2106. https://doi.org/10.1021/jo00006a026

30. Armarego, W. L. F.; Perrin, D. D. Purification of Laboratory Chemicals, 4th Ed. Butterworth Heinemann, 2002.

31. Hodous, B. L.; Fu, G. C. J. Am. Chem. Soc. 2002, 124, 10006-10007. https://doi.org/10.1021/ja027466x

32. Wiskur, S. L.; Fu, G. C. J. Am. Chem. Soc. 2005, 127, 6176-6177. https://doi.org/10.1021/ja0506152

33. Allen, A. D.; Baigrie, L. M.; Gong, L.; Tidwell, T. T. Can. J. Chem. 1991, 69, 138-145. https://doi.org/10.1139/v91-022

34. Wilson, J. E.; Fu, G. C. Angew. Chem. Int. Ed. 2004, 43, 6358-6360. https://doi.org/10.1002/anie.200460698

35. Ruden R. A. J. Org. Chem. 1974, 39, 3607-3608. https://doi.org/10.1021/jo00938a041

36. Papageorgiou, C. D.; Ley, S. V.; Gaunt, M. J. Angew. Chem. Int. Ed. 2003, 42, 828-831. https://doi.org/10.1002/anie.200390222 